\title{
Pengaruh beban lampu terhadap tegangan, arus, dan rpm pada turbin angin cross flow 8 sudu
}

\author{
Febrian Nur Syamsi ${ }^{*}$, Mochamad Arif Irfa ${ }^{\prime}{ }^{2}$, Basuki ${ }^{3}$ \\ Prodi Teknik Mesin, Fakultas Teknik, Universitas Hasyim Asy'ari ${ }^{1,2,3}$ \\ JI. Irian Jaya 55 Tebuireng Tromol Pos IX Jombang Jatim Telp. (0321) 861719 (Hunting), \\ 864206, 851396, 874685 Fax. 874684 \\ Corresponding author: febriannursyamsi@gmail.com
}

\begin{abstract}
Alternative energy is a source of energy found in nature that can be directly used freely. Besides, the availability of alternative energy is infinite and can be managed sustainably. This wind energy source can be used as an electricity generator by building several wind turbine units. The problem in this research is how the influence on the performance of the 8 blades cross-flow wind turbine, while the purpose in this study is to find out how the load on the performance of the blades of 8 blades. The type of research I use is quantitative research. For the author's method using an experimental method, the free load variable lights 0, 3, 6, and 9 Watts and the dependent variables are current, Voltage, and RPM. The results showed that the 8 blades cross-flow wind turbine had the best performance at 0 -Watt load which produced 0 Amperees current, 13.8-Watt Voltage, and 354.92 RPM. while the lowest performance on a 9-Watt lamp load which produces a current of 0.2088 Amperees, a Voltage of 9.08 Volts and Rpm 301.08, the current has increased, this is because the current is directly proportional to the load power, while the Voltage and RPM have decreased because generator Voltage and RPM are inversely proportional to the load power used.
\end{abstract}

Keywords: wind turbine, Voltage, current, and RPM.

\begin{abstract}
Abstrak
Energi alternatif merupakan suatu sumber energi yang terdapat di alam yang dapat langsung digunakan dengan bebas. Selain itu, tersedianya energi alternatif ini tak terhingga dan bisa dikelola secara berkelanjutan. Sumber energi angin ini dapat dimanfaatkan sebagai penghasil listrik dengan membangun beberapa unit turbin angin. Permasalahan dalam penelitian ini adalah bagaimana pengaruh beban terhadap unjuk kerja turbin angin jenis cross flow 8 sudu, sedangkan tujuan dalam penelitian ini adalah mengetahui bagaimana beban terhadap unjuk kerta turbin anggin jenis cross flow 8 sudu. Jenis penelitian yang penulis gunakan adalah penelitian kuantitatif. Untuk metode penulis menggunakan metode eksperimental, dengan variabel bebas beban lampu 0, 3, 6 dan 9 Watt dan variabel terikatnya yaitu arus, tegangan dan RPM. Hasil penelitian menunjukkan bahwa turbin angin cross flow 8 sudu yang memiliki kinerja terbaik pada beban 0 Watt yang menghasilkan arus 0 Ampere, tegangan 13,8 Watt dan RPM 354,92. sedangkan unjuk kerja terendah pada beban lampu 9 Watt yang menghasilkan arus 0,2088 Ampere, tegangan 9,08 Volt dan Rpm 301,08, arus mengalami peningkatan, hal ini disebabkan karena arus berbanding lurus dengan daya bebannya, sedangkan tegangan dan RPM mengalami penurunan karena tegangan generator dan RPM berbanding terbalik dengan daya beban yang digunakan.
\end{abstract}

Kata kunci: turbin angin, tegangan, arus, dan RPM. 


\section{Pendahuluan}

Sumber energi dasar yang masih digunakan di Indonesia saat ini adalah energi fosil, baik batu bara maupun minyak bumi. Namun, bahan bakar fosil sendiri merupakan sumber energi alam yang terbatas atau tidak dapat diperbaharui. Hal tersebut berimplikasi pada semakin menipisnya sumber energi fosil [9]. Data menyatakan bahwa persediaan batubara kurang lebih sekitar 7,3 - 8,3 miliar ton yang diperkirakan akan mengalami penurunan pada tahun 2036. Sementara itu, persediaan minyak bumi berkisar 3,7 miliar barel dan diprediksi akan habis pada tahun 2028. Sedangkan bahan bakar gas, pesediaanya berkisar 151,33 trilioncubic feet $(T C F)$ dan diprediksi akan habis pada tahun 2067 [3]. Oleh sebab itu, pihak pemerintah terus menerus mendorong pemanfaatan energi alternatif sebagai pengganti bahan bakar fosil.

Energi alternatif merupakan suatu sumber energi yang terdapat di alam yang dapat langsung digunakan dengan bebas. Selain itu, tersedianya energi alternatif ini tak terhingga dan bisa dikelola secara berkelanjutan. Salah satu sumber energi terbarukan yaitu energi angin. Energi angin memilki sifat yang fleksibel, sehingga dapat diterapkan diberbagai tempat, baik di daerah landai, dataran tinggi dan laut. Sumber energi angin ini dapat dimanfaatkan sebagai penghasil listrik dengan membangun beberapa unit turbin angin [6].

Selain itu turbin angin yang populer adalah turbin angin jenis cross flow biasanya sering dipakai pada pembangkit listrik tenaga air, keuntungan dari turbin angin jenis ini adalah kontruksinya yang lebih sederhana, dan operasi awal yang lebih terjangkau dibanding dengan jenis turbin lainya [2].

Turbin angina crossflow telah dirancang dengan sangat teliti untuk fleksibilitas, kemudahan dalam pemasangan dan perawatan yang lebih rendah memberikan daya terbarukan yang andal, kuat, dan aman, untuk menurunkan bergantungnya terhadap bahan bakar fosil dan mendorong perubahan kemasa depan untuk beralih ke energi terbarukan [5].

Berdasarkan penjelasan diatas penulis tertarik untuk melakukan penelitian tentang "Pengaruh variasi jumlah sudu dan beban terhadap unjuk kerja turbin angin jenis cross flow". Diharapkan dalam penelitian ini penulis dapat menghasilkan turbin angin vertikal jenis cross flow sebagai pengganti energi fosil yang dapat dimanfaatkan dan mampu menghasilkan energi listrik yang dapat dimanfaatkan di daerah - daerah terpencil yang belum terdistribusi aliran listrik.

\section{Tinjauan Pustaka}

Angin adalah sekumpulan aliran udara yang bergerak yang disebabkan oleh rotasi bumi dan karena adanya suatu perbedaan tekanan udara yang berada disekelilingnya, angin bergerak dari tempat yang bertekanan tinggi menuju tempat yang bertekanan lebih rendah dan angin bergerak dari tempat yang memiliki temperatur rendah ketempat yang memiliki temperatur lebih tinggi [4].

Turbin angin merupakan serangkaian alat yang berfungsi merubah energi angin menjadi energi gerak pada poros turbin yang kemudian dijadikan sebagai pemutar dinamo atau generator untuk menghasilkan listrik [4]. Desain turbin angin sangat banyak besaran arah putarannya, turbin angin dibedakan menjadi dua yaitu, turbin angin poros horisontal, dan turbin angin poros vertikal.

Turbin angin poros horisontal adalah turbin angin horizontal yang putaran poros utamanya mengikuti arah angin. Supaya baling-baling berputar dengan tepat, datangnya angin sebaiknya sejajar dengan poros turbin dan tegak lurus dengan arah putaran baling-baling. Kebanyakan turbin angin tipe ini memliki sudu yang menyerupai sayap pesawat terbang.

Turbin angin poros vertikal adalah jenis turbin poros vertikal yang gerak poros dan rotornya sejajar dengan datangnya angin dari segala penjuru arah angin, 
dengan sumbu vertikal memungkinkan untuk menempatkan dinamo dan komponen-komponen utama lainya dapat ditempatkan dekat dengan permukaan tanah, hal ini menyebabkan lebih mudahnya dalam proses perawatan [4].

Berikut ini merupakan sistem konversi energi angin, yang dapat dilihat pada Gambar 1.



Gambar 1. Sistem Konversi Energi Angin

Cara kerja turbin angin ialah merubah energi angin menjadi energi putar sudu, kemudian putaran sudu diteruskan ke rotor berfungsi mengerakan dinamo, yang nantinya akan menghasilkan listrik [6].

\section{Metode Penelitian}

Jenis penelitian yang penulis gunakan adalah penelitian kuantitatif. Untuk metode penulis menggunakan metode eksperimental dengan variable bebas beban lampu dan variabel terikatnya dalah arus tegangan dan RPM yang kemudian menghasilkan turbin angin jenis cross flow 8 sudu. Hasil yang diperoleh dari pengujian kemudian dianalisis dan mendapatkan kesimpulan. Berikut ini adalah flow chart penelitian yang dapat dilihat pada Gambar 2.

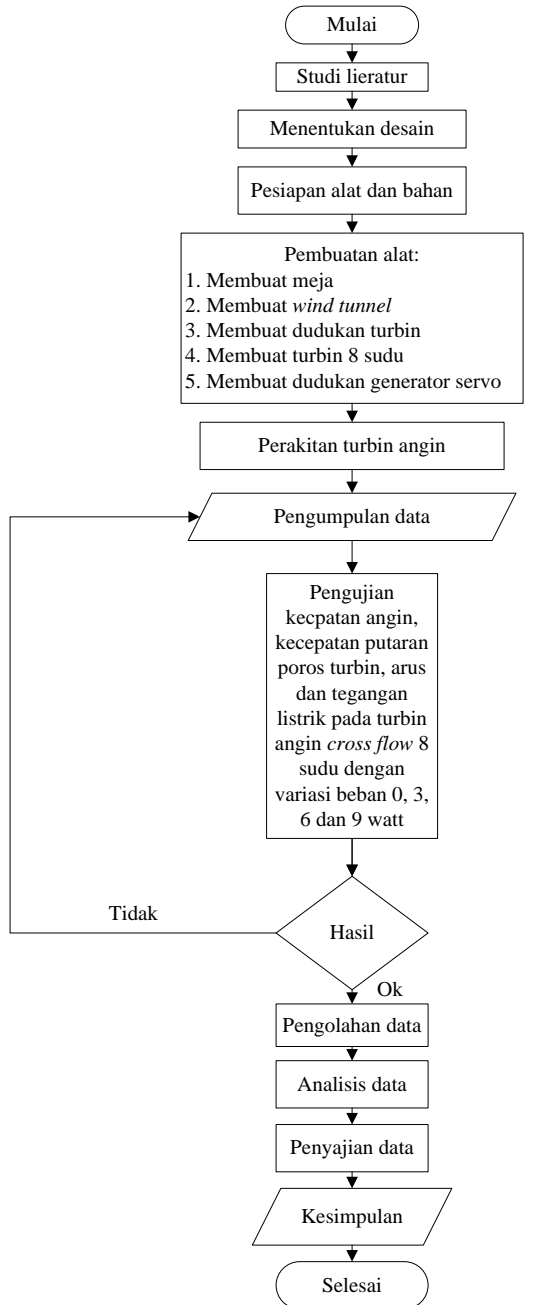

Gambar 2. Flow Chart Penelitian.

Variabel yang di gunakan dalam penelitian ini adalah sebagai berikut:

1. Variabel bebas

Variabel bebas merupakan variabel yang mempengaruhi dan yang menjadi sebab perubahanya variabel terikat. Pada penelitian ini varibel bebasnya adalah Jumlah sudu pada turbin dengan variasi 4,6,dan 8 sudu dan variasi beban lampu 3 Watt, 6 Watt dan 9 Watt.

2. Variabel terikat

Variabel dependent merupakan variabel yang dipengaruhi atau yang menjadi akibat karena adanya variabel bebas. Pada penelitian ini variabel terikatnya adalah arus, tegangan dan kecepatan putaran poros yang dihasilkan.

3. Variabel kontrol

Variabel kontrol merupakan variabel yang di kontrol dan 
dikendalikan. Pada penelitian ini variabel kontrolnya adalah turbin angin jenis cross flow8 sudu,diameter sudu, panjang sudu, kecepatan angin dan terowongan angin.

Berikut ini merupakan desain turbin angin cross flow 8 sudu dapat dilihat pada Gambar 3.

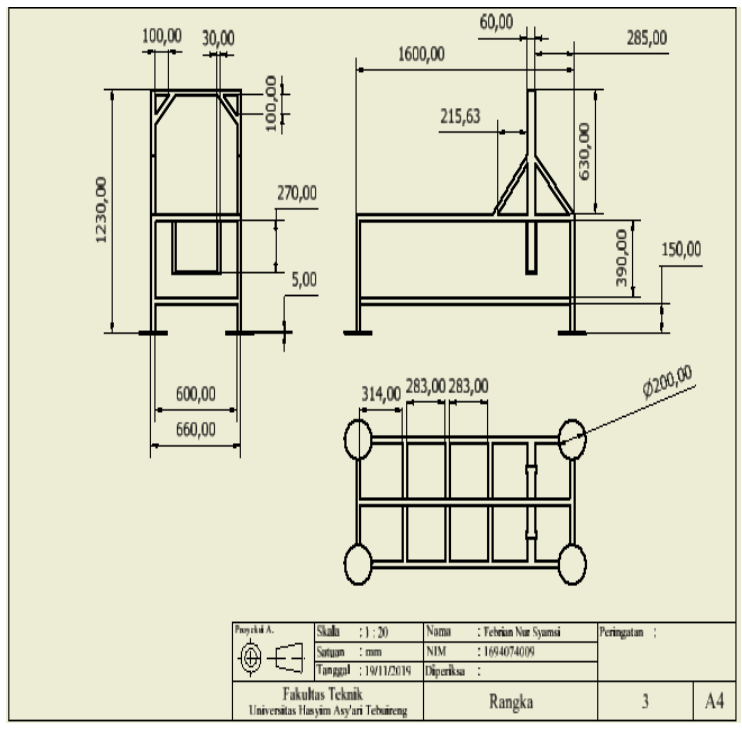

Gambar 3. Kerangka Meja

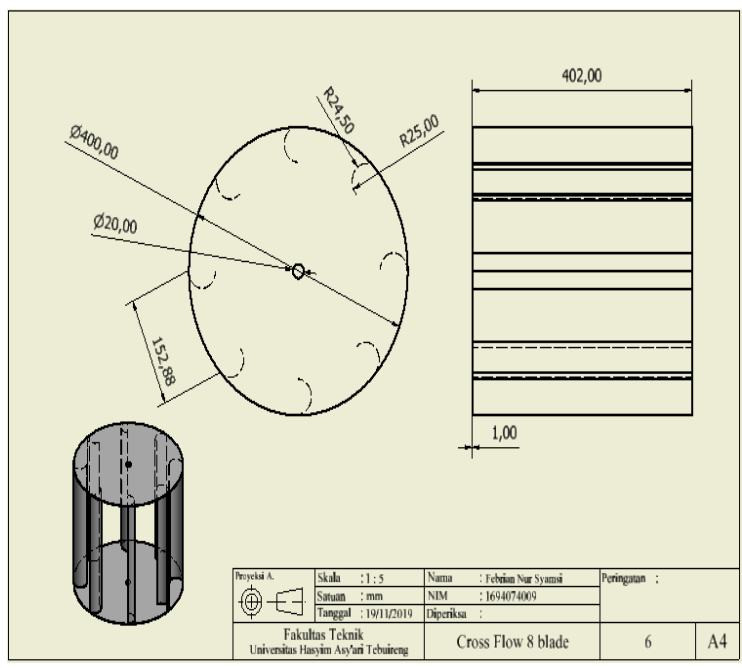

Gambar 4. Cross Flow 8 Sudu

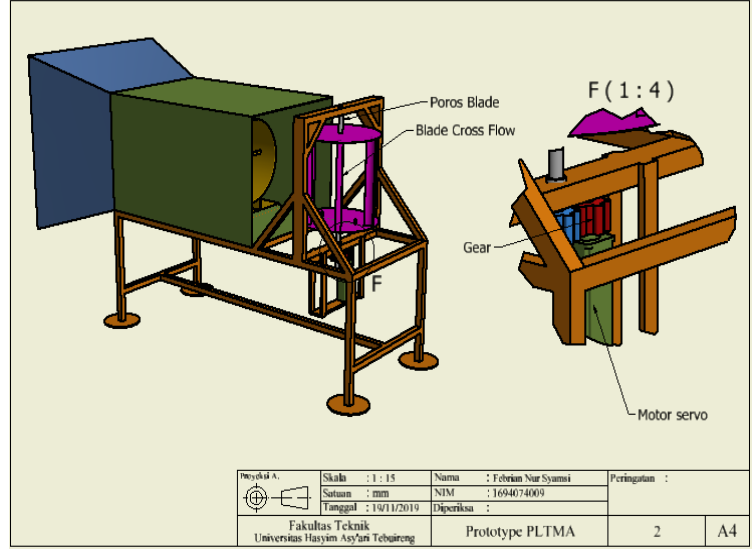

Gambar 5. Turbin Angin Cross flow 8 Sudu

Penulis mengumpulkan data secara langsung dari referensi buku, jurnal dan lain sebagainya yang berkaitan dengan pengaruh beban lampu terhadap tegangan, arus, dan RPM yang dihasilkan turbin angin cross flow 8 sudu, kemudian dilanjutkan dengan menetukan desain alat dilanjutkan dengan persiapan alat dan bahan yang akan dipakai dalam penelitian, dilanjutkan membuat kerangka mesin yang meliputi: (pembuatan kerangka wind tunnel, pembuatan dudukan kipas penggerak atau blower ventilator, pembuatan ducting, pembuatan dudukan poros sudu, penyenaian poros sudu, pembuatan 8 sudu, dilanjutkan perakitan keseluruhan part), kemudian dilanjutkan pengujian turbin angin cross flow yang telah dibuat meliputi pengujian kecepatan angin dengan menggunakan anemometer, setelah itu kecepatan putar turbin diukur dengan menggunakan tachometer, serta pengukuran tegangan dan arus generator dengan avometer, dengan beban lampu 0 , 3, 6, 9 Watt, setelah memperoleh hasil kemudian dilakukan pengolahan data , analisa data dan penyajian yang kemudian data tersebut dapat disimpulkan sesuai dengan hasil yang di dapat saat penelitan.

Dalam memperoleh data yang diinginkan pada penelitian ini penulis melakukan dengan cara mengukur:

1. Rotasi putaran poros permenit (RPM)

2. Tegangan

3. Arus 
Dalam penelitian ini analisa yang penulis gunakan adalah analisa komparasi yang membandingkan antara beban lampu 0, 3, 6 dan 9 Watt terhadap arus tegangan dan RPM pada turbin angin cross flow 8 sudu.

\section{Hasil dan Pembahasan}

Data hasil pengujian dari turbin angin cross flow 8 sudu dengan variasi beban 0, 3, 6 dan 9 Watt, apa dilihat pada Tabel 1 .

Tabel 1. Nilai Hasil Pengujian Tegangan, Arus dan RPM Turbin Angin Cross Flow 8 Sudu

\begin{tabular}{ccccc}
\hline No & $\begin{array}{c}\text { Beban } \\
\text { (Watt) }\end{array}$ & $\begin{array}{c}\text { Tegangan } \\
(\mathrm{V})\end{array}$ & $\begin{array}{c}\text { Arus } \\
(\mathrm{A})\end{array}$ & Rpm \\
\hline 1 & 0 & 13.8 & 0 & 354,92 \\
\hline 2 & 3 & 11.08 & 0.1152 & 328,78 \\
\hline 3 & 6 & 10 & 0.1864 & 304,74 \\
\hline 4 & 9 & 9.08 & 0.2088 & 301,08 \\
\hline
\end{tabular}

Berdasarkan dari hasil Tabel 1 menunjukka hasil pengujian dari turbin angin cross flow 8 sudu dengan menggunakan beban lampu 0, 3, 6 dan 9 Watt menunjukkan bahwa semakain banyak beban lampu yang dipakai maka arus akan mengalami peningkatan, hal ini disebabkan karena daya beban lampu berbanding terbalik dengan kecepatan putaran generator, semakin banyak beban lampu yang digunakan maka kecepatan putaran generator menurun, jumlah beban lampu yang terpasang pada generator mempengaruhi kecepatan putaran generatormaka kecepatan putaran generator akan semakin turun seiring dengan bertambahnya beban lampu yang digunakan [8]. Sedangkan nilai tengangan berbanding terbalik dengan daya semakin banyak beban lampu yang digunakan maka nilai tegangan generatornya mengalami penurunan [8]. Sedangkan nilai RPM akan mengalami penurunan. Karena hukum Ohm menyatakan nilai tegangan berbanding lurus dengan arus yang mengalir, arus tersebut ditentukan oleh daya beban digunakan, semakin besar daya bebanya maka arus yang mengalir kebeban tersebut akan mengalami peningkatan[8].

Hubungan beban lampu 0, 3, 6 dan 9 Watt terhadat tegangan yang di hasilkan turbin angin cross flow 8 sudu dapat dilihat pada Gambar 6.

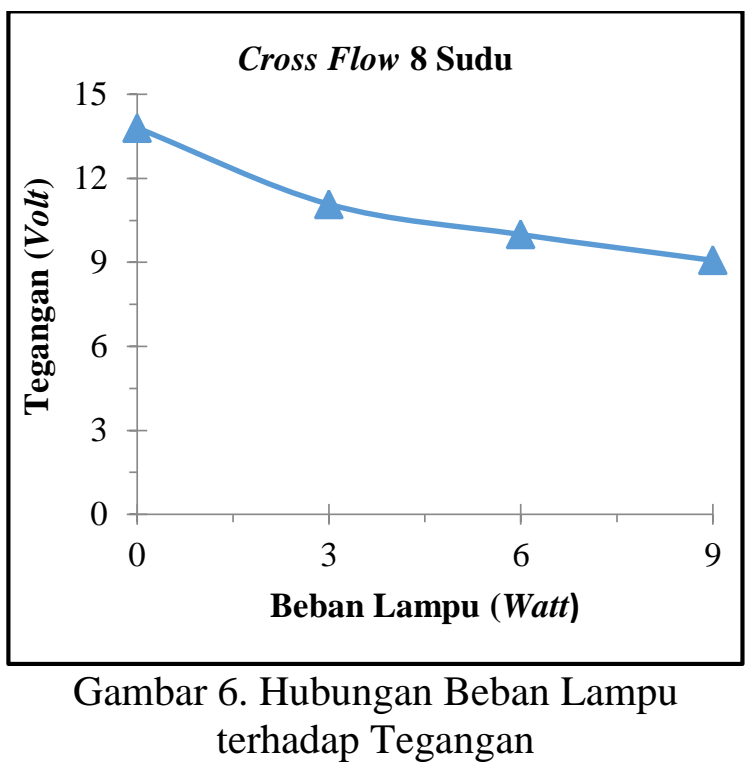

Berdasarkan gambar 6 menunjukkan hubungan antara beban lampu 0, 3, 6 dan 9 Watt terhadap tegangan pada turbin angin cross flow 8 sudu, ketika menggunakan beban lampu 0 Watt menghasilkan tegangan 13,8 Volt, ketika menggunakan beban lampu 3 Watt menghasilkan tegangan 11,08 Volt, ketika menggunakan beban lampu 6 Watt menghasilkan tegangan 10 Volt dan ketika menggunakan beban lampu 9 Watt menghasilkan 9,08 Volt. Berdasarkan pemaparan diatas dapat disimpulkan bahwa semakin banyak beban maka akan semakin kecil tegangan yang dihasilkan begitu jugasebaliknya ketika beban yang digunakan semakin kecil maka tegangan yang dihasilkan akan semakin besar.

Hubungan beban lampu 0, 3, 6 dan 9 Watt terhadap arus yang dihasilkan turbin angin cross flow 8 sudu, dapat dilihat pada Gambar 7. 


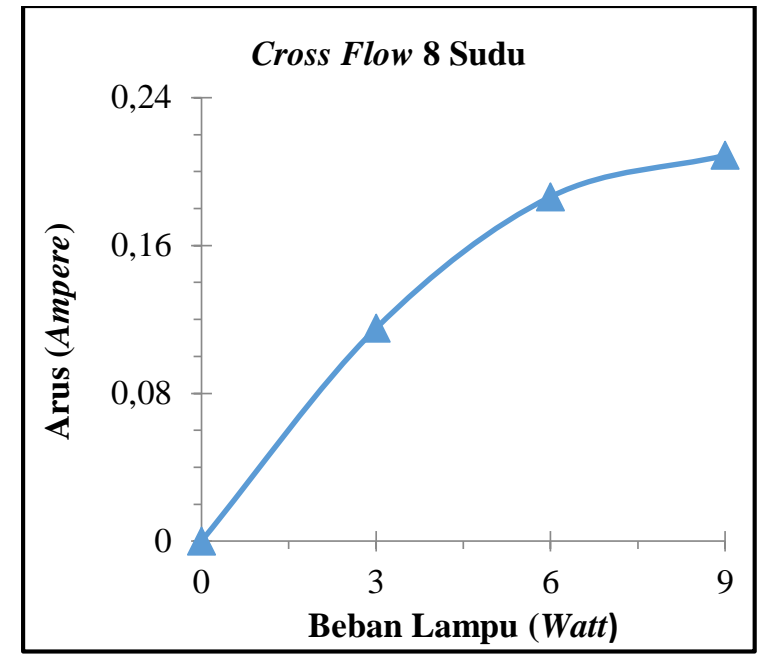

Gambar 7. Hubungan Beban lampu Terhadap Arus

Berdasarkan Gambar 7 menunjukkan hubungan antara beban lampu 0, 3, 6 dan 9 Watt terhadap arus pada turbin angin cross flow 8 sudu, ketika menggunakan beban lampu 3 Watt menghasilkan arus 0,1152 Ampere, ketika menggunakan beban lampu 6 Watt menghasilkan arus 0,1864 Ampere dan ketika menggunakan beban lampu 9 Watt menghasilkan arus 0,2088 Ampere. Berdasarkan pemaparan diatas dapat disimpulkan bahwa semakin banyak beban lampu yang digunakan maka arus yang dihasilkan akan mengalami peningkatan begitu sebaliknya ketika beban lampu yang digunakan semakin kecil maka arus yang ihasilkan juga akan semakin kecil.

Hubungan beban lampu 0, 3, 6 dan 9 Watt terhadap turbin angin cross flow 8 sudu, dapat dilihat pada Gambar 8.

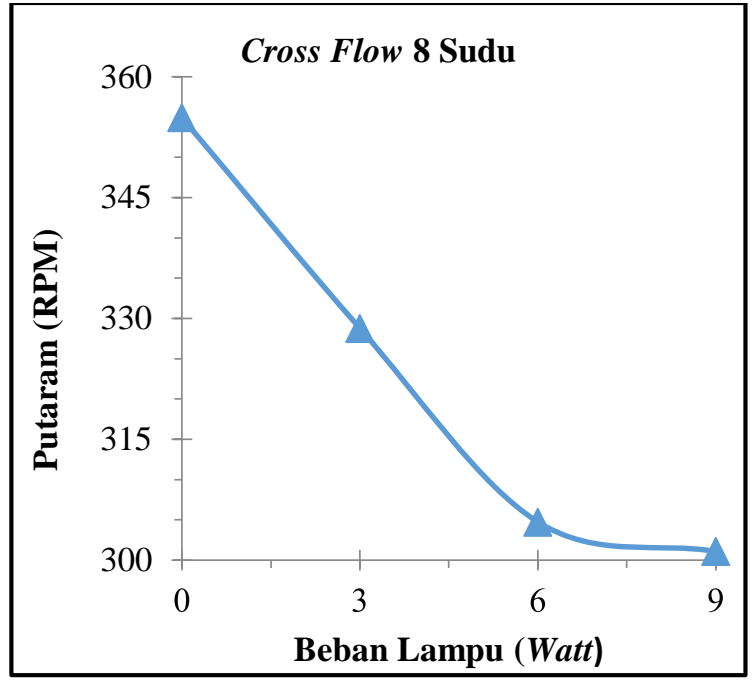

Gambar 9. Hubungan Beban Lampu Terhadap RPM

Berdasarkan Gambar 8 menunjukkan hubungan antara beban lampu 0, 3, 6 dan 9 Watt terhadap tegangan pada turbin angin cross flow 8 sudu, ketika menggunakan beban lampu 0 Watt menghasilkan RPM 354,92, ketika menggunakan beban lampu 3 Watt menghasilkan RPM 328,78, ketika meggunakan beban lampu 6 Watt menghasilkan RPM 304,74 dan ketika menggunakan beban lampu 9 Watt menghasilkan RPM 301,08. Berdasarkan pemaparan diatas dapat disimpulkan bahwa semakin besar beban lampu yang digunakan maka akan semakin kecil nilai RPM yang dihasilkan begitu juga sebaliknya ketika beban lampu yang digunkan semakin kecil maka nilai RPM akan semakin besar.

\section{Kesimpulan}

Berdasarkan hasil data pengujian turbin angin cross flow 8 sudu dapat disimpulkan bahwa:

1. Hasil penelitian menunjukkan bahwa turbinangin cross flow 8 sudu yang memiliki kinerja terbaik pada beban 0 Watt yang menghasilkan arus 0 Ampere, tegangan 13,8 Watt dan RPM 354,92. sedangkan unjuk kerja terendah pada beban lampu 9 Watt yang 
menghasilkan arus 0,2088 Ampere, tegangan 9,08 Volt dan RPM 301,08.

\section{Referensi}

[1] Artikel, 2008. (http://alpensteel. com/article/126-113-energi-lainlain/2473 optimali sasi - ektraksi energi - angin - kecepatan - rendah di - indonesia, diakses 18 Oktober 2019).

[2] Dhadung, Prihananto 2017. "Uji Eksperimental Pengaruh Sudut Kemiringan Sudu Posisi Vertical Turbin Cross Flow Dan Sudut Pengarah Aliran (Guide Vane) Terhadap Daya Poros Yang Dihasilkan Pada Sistem Pemulihan Energi Terintekgrasi Denga Menara Pendingin". Jurnal Teknik Mesin.

[3] ESDM. 2018. Indonesia Energy Efficiency and Consrvation Converence And Exhibiton. Jakarta 2018.

[4] Pengertian Angin. 2019. (https://id.wikipedia. org/wiki/Angin, diakses 16 Oktober 2109).

[5] Pengertian Turbin Angin 2019. (Cross flowhttp: //crossflow energy.co.uk /cross flow -windturbine/\#, diakses 16 Oktober 2019).

[6] Ruzita Sumiati, Khairul Amri, Hanif. 2014. "Rancang Bangun Micro Turbin Angin Pembangkit Listrik Untuk Rumah Tinggal di Daerah Kecepatan Angin Rendah". Prosiding Seminar Nasional Sains dan Teknologi. Jurnal Teknik Mesin.

[7] Sando, Wardani Krisna. 2017. "Pengaruh Jumlah Sudu Terhadap Kinerja Turbin Angin Darius Tip H”. Jurnal Teknik Mesin.

[8] Supardi, Agus dkk. 2017. "Pengaruh Kecepatan Puaran Dan Beban
Terhadap Keluaran Generaor Induksi 1 Fase Kecepatan Rendah". Jurnal Teknik Elektro.

[9] Wahyu, Permadi Mochamad Fachrudin. 2018. "Uji Eksperimental turbin Agin Sumbu Vertikal Jenis 